\title{
State National Policy as a Factor of Ethnic Integration in Russian Society
}

\author{
Yuri V. Popkov
}

\begin{abstract}
Dr. Sci. (Philos.), Professor, Deputy Director for Science, Director of the Ethno-social Research Department, Institute of Philosophy and Law, Siberian Branch of RAS (Novosibirsk) yuripopkov54@mail.ru
\end{abstract}

\begin{abstract}
This article analyses a series of conceptual problems of contemporary Russian national policy, with an emphasis on the identification of its role as an interethnic integration factor. The problem is becoming more urgent in multiethnic regions, particularly in Siberia. The article shows that the problem of regulating ethnosocial processes, which are part of interethnic relations, has become global with regard to society's growing ethno-cultural complexity at all levels of its organisation. The author stipulates the need for national historical experience and established traditions of scientific understanding in the implementation of national policies. Rigid long-standing controversy between the supporters of civic (political) and ethnic (cultural) interpretations of the nation has not led to a clear victory of either party. Therefore, to describe these phenomena the author proposes two terms: nation-state phenomenon and ethno-national phenomenon. In contrast to the constructivist position in understanding the nation, the author defends the view that the nation is not only a form of collective consciousness, but also collective existence, collective action, and collective subjectivity. The author reasons for complementary public-civic and ethnic identities. Ethno-social processes are considered as an integrated object of national policy. The development of separate ethnic groups is represented as an interdependent development within the local and regional ethnic community, which is interpreted as an elementary object of the empirical study of ethno-social processes. The author justifies the need for regional models of national policy on the basis of the current problems and main trends in the ethno-social development of the peoples of Siberia. This takes into account the specifics of objective processes that operate in local interethnic communities. The author believes that implementation of conceptual paradigms by local authorities is an important condition of ethnic integration within Russian society.
\end{abstract}

Keywords: Nation, national policy, ethnic relations, region, ethno-social processes, integration.

DOI: $10.21684 / 2587-8484-2017-1-1-82-94$

Globalisation is a leading trend in recent worldwide development, which is characterised by diverse, ambiguous and contradictory effects. With regard to socio-cultural dynamics, its dominant manifestations are, on the one hand, the strengthening of integration and unification processes, as well as interconnection and interdependence of different countries and nations; on the other hand, globalisation is linked to growth in multi-ethnicity and cultural complexity, and the development of various forms of fragmentation and localisation. Accordingly, it is connected to
Citation: Popkov Yu. V. 2017. "State National Policy as a Factor of Ethnic Integration in the Russian Society". Siberian Socium, vol. 1, no 1, pp. 82-94. DOI: 10.21684/2587-8484-2017-1-1-82-94

effects of rapprochement and unification of cultures and the isolation of their representatives.

The tendency to revive national cultural values and customs is intensifying as a reaction to the influence of globalisation, which leads to the levelling of ethno-cultural diversity. This situation today is often called an ethnic boom or ethnic renaissance. In many respects, it is caused by the growth of globalisation processes, which are inevitably accompanied by the unification and "massification" of cultures. 


\section{As L. V. Smargunov put it,}

"Globalist universalism is accepted and at the same time questioned, since delusion by the effectiveness of the new totality of life forms is opposed to the 'soil', culture, meaning and cosiness of the home. At the same time, the inability to keep the 'home' intact under the onslaught of a clearly expressed need for globalisation and modernisation creates a dramatic sense of rupture, incompatibility, loss, and in some cases, tragic apprehension of an impending catastrophe, albeit in a mild 'sunset"' [24: 178-179].

The current situation refutes clearly F. Fukuyama's famous thesis about the "end of history". History does not merely continue: it intensifies, becoming a very mobile, constantly changing and problematic value within the framework of the new reality — nonlinear socio-cultural dynamics [9]. One of its characteristics is expanding and deepening cultural diversity, which includes ethno-cultural diversity as a significant component. The contradictory and problematic situation is aggravated by the ongoing processes of urbanisation and large-scale internal and cross-border migration, which lead to complexity in social organisation in terms of multiethnicity on the global, as well as regional and local levels.

There is every reason to say that modern globalisation leads to the development of a heterogeneous unity. At the same time, national (ethnic) communities change and enrich themselves in the process of interaction and mutual influence, yet remain relatively independent. The new systemic integrity that is emerging as a result of globalisation must be understood as a developing unity of diversity. Awareness of this fact led to important decisions taken by global organisations, e.g., the UNESCO Universal Declaration on Cultural Diversity (2001) and the World Day for Cultural Diversity, celebrated annually on 21 May (proclaimed by the UN General Assembly in 2002).

Within the framework of general cultural complexity, ethno-cultural complexity is of particular importance, since the tension of interethnic relations, which arise inevitably as a result of the processed mentioned, causes many problems. Among them there is a threat to the security of certain regions and entire states. Moreover, this situation is usually associated not only with ethno-cultural problems proper, regulated by cultural policy. Ethno-social problems, linked to insufficient order in ethno-social processes, have an important influence here. These processes should be regulated by national (or ethnonational) policies.

In these conditions, the problem of understanding the possibilities for integration in society at different levels is increasing in importance. The search for mechanisms (primarily implemented in national state policy) adequate to the increasing ethno-cultural complexity of the modern world is becoming urgent. At the same time, it is important to consider the practical historical experience of different countries, as well as the traditions of its academic comprehension. National policy issues are relevant from the point of view of both practical implementation and appropriate methodological and theoretical support.

Obviously, this topic concerns a rather wide range of problems. The specific task of this article is to formulate and discuss the most significant conceptual issues of modern national policy in Russia regarding its influence on the development of social integration potential, considering the global and internal political context. We will advocate our position using theoretical arguments and the results of mass and expert surveys conducted recently in the Siberian regions ${ }^{1}$.

First of all, the problem of interethnic relations, as an important component of ethno-social processes, has existed and continues to exist in virtually all countries which are in varying degrees multiethnic. Moreover, the problem is intensifying under the influence of democratic development, moderni-

\footnotetext{
In particular, the author uses the results of mass and expert interviews conducted under his general supervision in 2013-2014 (mass poll organised by E. A. Erokhin). The interviews concerned the issues of ethno-social development and ethno-national politics in certain regions of Siberia: the Khanty-Mansi Autonomous Okrug - Yugra, the Novosibirsk region, and the Republic of Altai. More than two 2,000 were questioned.
} 
sation and technological progress. Therefore, its management refers to key elements of many modern states' domestic policies.

It is appropriate to link the fundamental conceptual foundations of practical activities for the implementation of national state policy with the main types of scientific rationality - classical, nonclassical and post-non-classical. Accordingly, it is possible to distinguish three dominant models of national policy in the world, based on these types of rationality: an integrative-assimilation model, realised without the factor of ethnic diversity; an integrative-adaptive model, built with diversity in mind; and spontaneously relativistic (multicultural), which goes back to postmodernism and cultural relativism and focuses on the situational approach and anti-crisis management of interethnic relations [7].

These models of national policy are implicitly embedded in the managerial decision-making process. Rooted in deep layers of rationality and associated with the dominant paradigms of scientific knowledge of their time, they are not always understood even by their practitioners. This does not prevent their presence in reality. One should also bear in mind that a "pure" model exists only in theory. In the practical activities of the governing bodies, as a rule, elements of different models coexist, though one may dominate.

In the modern era there is a marked change in the principles underlying national policy. Even the USA, which considered itself a single, integrated nation for a long time, abandoned the "melting pot" policy that could not cope with the task of "melting" ethnic multiculturalism. The nation switched to the "salad bowl" ideology, which recognises the existence of ethnocultural diversity. It does not solve serious problems, through. S. Huntington writes about it, identifying issues that, in his opinion, could in the coming years lead to dramatic changes for the USA, with the country acquiring totally different state principles and changing its national identity [10: 33-34].

There are certain grounds for such an assessment, including existing intensifying separatist sentiments. In California, the "Yes California" movement is reviving and its supporters advocate the withdrawal of the state from the USA. At present, its leaders have received permission to collect signatures in support of a referendum on such changes to the regional constitution to allow voting on this issue [25]

Donald Trump, the new US President, chose a new way to address existing problems in the field of migration policy practically immediately after his inauguration. He signed a decree on the construction of a solid wall along the entire border with Mexico, more than $3,000 \mathrm{~km}$ in total [30]. This decision caused a wave of protests, split American society and strengthened separatist movements in many states of the country.

Western Europe is another striking example that illustrates the difficulty in the regulation of processes caused by increased ethnic and cultural complexity. A few years ago, the leaders of some countries (Germany, France and the UK) declared multiculturalism policy a failure. The situation was further aggravated by large-scale refugee flows from Middle Eastern countries subject to "colour revolutions" and military conflicts. Many experts consider the situation in Europe as a migration crisis with possibly catastrophic consequences. The situation seems to be not only a migration crisis but also as a crisis of national (or ethno-national) policy. Its conceptual bases and implementation fail to solve the problem of ethnic integration for European nations.

Russia, after the collapse of the USSR in the 1990 s, has been tested not only by "shock therapy", liberalisation, dramatic socio-economic and political transformations, but also by the escalation of ethnonational movements, an exacerbation of interethnic relations, and significant changes in the nature of ethno-social processes. "Take as much sovereignty as you can absorb", the epoch-making phrase of B. Yeltsin, the head of the Supreme Soviet of the Russian Soviet Federative Social Republic (RSFSR), was of great importance for the leaders of Russia's autonomous regions. He pronounced it in Kazan in August 1990, thereby provoking a wave of "sovereignty parades" in the autonomous republics. It is known that many of them adopted laws that contradicted the federal legislation (on the supremacy of republican laws over Russian laws, on state sovereignty, on their own citizenship, on exclusive rights 
to subsurface resources, on privileges in rights for titular nations, etc.) [4]. One of the consequences of this policy was growing inequality among the RF subjects in a number of fields. The federal government was forced to make concessions and costly compromises in order to preserve the country's integrity. Only in the early 2000s was regional legislation brought into line with federal legislation. Although the equality of the RF subjects is proclaimed in the country's fundamental law, this inequality has not been completely overcome.

Relative stabilisation of the ethno-social situation occurred in the 2000s, which created an illusion of well-being in this field. Apparently, the federal authorities were so convinced of this illusion that in October 2001 the Ministry for Federation Affairs, National and Migration Policy was abolished (it had existed since May 2000). During the entire post-Soviet period, federal agencies did not have a clear idea of the nature, content and place of national policy in the structure of state power. This is evidenced by the constantly changing names of the bodies responsible for national policy issues in 1991-2000: the RSFSR State Committee of National Policy, the State Committee of Federation and Nationality Affairs, the RF Ministry of Nationalities and Regional Politics, the Ministry of Nationality and Federal Relations, the Ministry of Regional and National Policy, the Ministry of National Policy.

After the liquidation of the Ministry of Federation Affairs, National and Migration Policy, government curatorship of the latter was transferred to V. Yu. Zorin, a minister "without a portfolio". Later, answering the question as to why the ministry had been abolished, he said:

"The liberal Western approach to ethnic politics won. The state withdrew from this sphere, leaving everything to civic society, which is not yet ready for the task. The ministries and agencies responsible for state national policy were liquidated in practically all the subjects of the Federation, and the specialists who worked there left the civic service" [31: 19].

Subsequently, national policy issues were transferred to the Ministry of Culture and, after the events in Beslan in the Chechen Republic (the hostage- taking in a school), to the Ministry of Regional Development [11].

The illusion of prosperity in the sphere of national policy was dispelled after the mass unrest on Manege Square (Moscow) in December 2010. It became clear that this policy, and the state of the processes it is called upon to regulate, are the most important components of state policy, the basis of Russia's national security.

The unrest on Manège Square brought the close attention of the authorities to the problems of the modern state and affected national policy, leading to a series of significant events. The most notable among them are: the publication in January 2012 of an article by Vladimir Putin (then Prime Minister and presidential candidate) Russia - The National Issue; the establishment of the Presidential Council for Interethnic Relations in June 2012; the approval of the 2025 RF State National Policy Strategy in December 2012 (hereinafter the Strategy) [26]; the adoption of a federal target programme "Strengthening the Unity of the Russian Nation and the Ethno-Cultural Development of the Peoples of Russia (2014-2020)" in August 2013 [8]; the establishment of the Federal Agency of Nationality Affairs in March 2015.

Considering the doctrine, the content of the Strategy is of special importance, because it expresses the official directives in state national policy that constitute the fundamental basis of the activities of the federal, regional and municipal authorities. These activities are aimed to strengthen civic unity, to improve ethnocultural development, to harmonise ethnic relations, etc. It should be noted, however, that after the Strategy's approval, a number of important and not completely clarified issues, related to the theoretical and methodological foundations and conceptual rigour of the Strategy text, remain unanswered. The same goes for the correspondence of the set tasks to the real state of affairs in this sphere of public life and the potential for interethnic integration in Russian society. It is important to consider public opinion, including various groups of experts on topical issues of Russian modern national politics.

We have already touched up on the conceptual aspects of national policy [18-20]. We are going to continue this topic and to outline some important issues. 
Although the Strategy recognises Russia as a multinational state with interethnic relations, in fact it deals only with one nation: the Russians. In comparison with the Concept of the RF State National Policy (1996), we observe a different approach. If earlier the nation was considered an ethno-cultural phenomenon, now it appears to be a nation-state (the Russian nation). The term Russian nation, used in the Strategy, does not correspond to the meaning of the term national used in other cases, for the latter does not have a political (civic) sense, as in "Russian nation", but an ethnical (ethno-cultural) sense. This is indicated by such concepts as national policy, nationality, interethnic harmony, etc. Thus, confusion in terminology is visible in the Strategy itself. If one tries to follow its logic to understand the Russian nation, the question arises: what interethnic relations are there if there is only one nation in the country, i.e. the Russian nation?

Certain groups of Russian researchers view a nation as a political (civic) community, and an ethnic group as a socio-cultural community. In everyday life, however, and in academic and political discourse, there is no clear distinction between these concepts. The term national is used, as in the Strategy, in the sense of state, civic (national income, national interests of the state, etc.), but also in the sense of ethnic, ethno-cultural (national culture, interethnic relations, etc.). The multiple interpretations of the concept of nation and its derivatives are largely associated with the various traditions of its usage. Anglo-Saxon culture uses it in the sense of a nation-state, while in the German and Russian cultures it designates a nationculture. In addition, the regulatory and legal framework of the national policy operating in the form of the law "On National and Cultural Autonomy" preserves the tradition of the Soviet period: the nation is treated in a cultural sense (nation $=$ culture).

It is worth noting that the word nation, translated from the Latin, means 'a tribe, a people'. As U. Connor wrote, "when this word was introduced into English in the late $13^{\text {th }}$ century, it was used in its original sense to designate kinship" [6: 61].

In this respect, the conclusion of T. K. Oomenman, the President of the International Sociological Association in 1990-1994, is extremely fitting. He wrote,
"Any attempt to define a nation (nationality) as a political substance is untenable, because a) it leads to yet another conceptual confusion, namely, a state with a nation; b) this is empirically incorrect, since Napoleon's principle 'Every nation is a state, in each state there is a single nation' was not implemented even within the limits of Western Europe, i.e. the cradle of mono-national states" [16:25].

The long and quite arduous debate between the supporters of civic (political) and ethnic (cultural) interpretations of the nation has not led to a clear victory of either party. The ideological hegemony of Western political concepts of the nation, expressed by such organisations as the UN, was not able to stop the ethnic renaissance observed in the late $20^{\text {th }}$ century, associated with the concept of a cultural nation. Therefore, the everlasting confrontation and aggressive efforts to displace the ethno-cultural interpretation of the nation are no longer relevant. Of great importance currently is the reflexive communication of these two perspectives. In view of the current situation, it is more correct to say that a nation exists in two basic forms: a nation of culture, and a nationstate. This is all the more important, as the authorities directive to substantiate the understanding of Russia as a united (or single) nation contradicts the constitutional provisions of Russia identifying it as a multinational state (multinational people), as well as the Russian tradition of considering a nation as an ethnic and cultural phenomenon. Therefore, the issue is not to replace one meaning of the concept with another (as some of our academics have insisted for many years), but the problem is the terminological distinction itself. To distinguish the phenomena, it is advisable to use two terms: ethno-national and nation-state (or national) respectively.

It is also important to know that national policy usually refers to the policy of different ethnic (ethno-social, ethno-cultural) subjects. Hence, it is advisable to call it not national policy but ethno-national policy. This point of view is supported by certain works [1;23].

The enforcement of a civic (political) meaning of the concept of nation could lead to results contrary to those expected by its advocates: it cannot integrate but only disintegrate, divide the society at the ele- 
mentary stage of discussion of this timely topic. This happened with the idea of a draft law on the Russian nation. V. A. Mikhailov proposed to adopt the law at a meeting of the Presidential Council for Interethnic Relations (31 October 2016). The President supported this idea, saying "A law on the Russian nation is possible and necessary to implement, and we should start working on it" [13].

Immediately after this, a fierce public debate began about the rationale of such a law. The vast majority of experts, both Russians as representatives of the predominant nationality and other peoples, expressed a markedly negative attitude to the idea $[2 ; 5]$. Both groups fear infringement on their national (ethnic) community or even identity. The situation is aggravated by the fact that high-ranking officials express their own vision of this serious problem, which, in our opinion, is not quite adequate, and the public perceives their opinion as an official position. Thus, V. R. Medinsky, Minister of Culture of the RF, believes that the dispute about the concepts of Russian ethnicity and Russian nationality is a non-issue, believing that they are essentially identical, and assesses the distinction as a matter of "taste or preference" [12].

The idea of a possible draft law on Russian nation is of interest to non-specialists as well. Common users of the global network are quite critical and, in fact, give a correct diagnosis of the emerging problem. Here is one such opinion: "I hope the law will not determine that everyone who has a Russian passport is Russian. If so, this is nonsense... If not, then what do we need this law for?" [22].

The most dangerous issue is that the law could provoke ethnic separatism. Such fears are already present in the information sphere.

"In the Kabardino-Balkarian Republic, shortly before the New Year, a congress of the Balkar people was held, which delivered an ultimatum to the regional authorities, threatening the secession of Balkaria from the republic. It seems that such outbursts of ethnic separatism will appear more often in the coming year while the law is being drafted" [5].

Apparently, the representatives of the Presidential Administration are trying to soften their position in light of the unfavourate public response to this law.
There is, therefore, no direct mention of the law in the official information about the session of the presidium of the Council on Interethnic Relations held on 15 December 2016; instead, there is information about the elaboration of proposals "On the normative regulation of relations in the sphere of strengthening the unity of the multinational people of the Russian Federation (Russian nation)". It also emphasises the need to study all opinions and the inadmissibility of hasty and ill-considered proposals [14].

At the same time, it should be noted that V.A. Tishkov, a member of the Academy of Sciences, the vicechairman of the Council presidium and the most active and persevering supporter of the political conception of the nation, has been appointed as the head of the temporary working group for the execution of this assignment. His position is not sufficiently rigorous from an academic point of view. At the time, he argued that the term nation (and nationalism) belonged to operational academic and political categories, and called the years-long debate on the issue a global and long-term hoax [27]. In his opinion, nation is just a metaphor which, however, has acquired a powerful emotional and political sense [28].

In late January 2017, following the session of the presidium of the Council on Interethnic Relations, V.A. Tishkov published an article stating his position on the nation [29]. The academician gives a very accurate description of many rather contradictory and complex processes related to the problem. At the same time, the most important of his provisions invite further discussion.

V. A. Tishkov questions the appropriateness of discussing "nations in terms of ethnicity" in relation to current circumstances. However, at the same time, he offers "to introduce a double meaning, that is, to designate two different types of community as a nation. These are: a community according to the principle of a state, and a community according to the principle of a culture" [29]. (We note that such meanings of the concept of nation have long existed in scientific discourse, as mentioned earlier.) Based on this, V. A. Tishkov believes that the formula a "nation of nations" is suitable to characterise multinational Russia and its multinational people. It seems that this formula can be accepted as a metaphor in 
common use, but it is not appropriate for academic or political language, especially for legislative recognition which requires unambiguous interpretation of the concepts and terminology. In fact, this formula does not add clarity to the matter under consideration for the reason that one concept implies two different meanings.

No less controversial is the interpretation of the very concept of nation. Firstly, we consider it, like the concepts of people and state, as a "socially constructed category". Secondly, the nation, from our point of view, is first and foremost a form of collective self-awareness (identity) for people who belong to a certain community which they consider to be a nation, i.e. a nation is understood as something limited by the sphere of consciousness or identity. Thirdly, the nation is "an instrument for achieving collective mobilisation and solidarity of civic or ethnic communities to obtain their sovereign status, to ensure security, to organise power and social order, to preserve and develop culture" [29].

There is a constructivist and instrumentalist interpretation of the nation's nature and the content of the corresponding concept. If one applies this content to this concept, then a natural question arises: what will the planned law on the Russian nation be about? Is it a law of Russian identity? In principle, this corresponds to V. A. Tishkov's proposal to adopt the federal law "Developing Russian Identity", which he expressed at the meeting of the Council on Interethnic Relations on 31 October 2016 [13]. In our opinion, however, Russian identity and the Russian nation are different phenomena, though closely related.

According to the constructivist approach, the issue of nation development can be reduced to a competent organisation of work towards a massive information impact on people's consciousness to achieve certain goals: to the development of given intellectual constructs. Modern information technology and media can solve many serious problems, including the mobilisation of people for mass action. We should bear in mind, however, that these technologies do not always work. The latest vivid example is the victory of D. Trump in the presidential elections in the USA, in spite of an unprecedented information campaign directed against him, as well as maximising the potential of the former administration. The result was directly opposite to the one that was purposefully organised. This fact itself proves that the media, even with administrative resources, are not all-powerful; there are other factors and mechanisms for shaping mass consciousness and mobilising people for certain actions.

As far as Russia is concerned, we note that the main task of national politics immediately after the events on Manège Square in December 2010 was to promote the idea of the Russian nation. This fully corresponded to the methodological guidelines of the constructivist approach in politics. However, soon there came an understanding of more complex mechanisms in the development of the Russian nation. In fact, a nation is not only a form of collective consciousness, but also of collective existence, collective action and collective subjection. Certainly, the constructs of consciousness play an important role in the lives of individuals, social groups and society as a whole, especially in the modern conditions of developed information technologies. However, it should be kept in mind that the constructs themselves are secondary, derived from other, objective conditions of existence, which are decisive in the final result. It is impossible to understand adequately the complex process of ensuring the national unity and interethnic integration of Russian society without taking these conditions into account.

In this regard, the idea expressed by V. A. Tishkov is valid. He quite rightly says that "national unity is ensured not only in the sphere of self-awareness, but also in the sphere of mobility and communication between citizens of one country"; he also finds the spatial cohesion of the nation to be no less important than its "spiritual and cultural bonds" [13]. There are, of course, additional important conditions and factors for the structuring of national unity, and they will be discussed subsequently.

Returning to the discussion of the draft law on the Russian nation, we would like to emphasise once again: there is no unambiguous meaningful interpretation of the concept of nation in the expert and public consciousness of Russian society. Many experts know this, including those who directly influence the im- 
portant decisions on national policy. Why, then, should we strive to adopt a federal law for the development of the Russian nation? There is no public consensus about this issue on the terminological and conceptual levels. Can such a step lead to consolidation? Obviously, it cannot. On the contrary, the mere announcement of the objective has led to a split. Persistent promotion of the idea will inevitably increase tension and lead to disintegration tendencies.

We are now going to proceed with issues concerning the conceptual foundations of state national policy related in one way or another to the problem of interethnic integration.

On the one hand, the Strategy determines the strengthening of Russia's state unity and integrity, the consolidation of pan-Russian civic self-awareness being the main strategic emphasis. On the other hand, it determines the preservation and development of the ethno-cultural diversity of the peoples of Russia, their ethno-cultural identity. The state orientation of the Strategy and its orientation towards the development of a Russian nation clearly express the idea of a nation-state model. The existing orientation towards the preservation and development of ethno-cultural diversity expresses the idea of a nation-culture model. Moreover, the first model dominates in the Strategy, although both are presented as coordinated. This is all the more relevant in the global context of the problem, as mentioned in the beginning of the article.

At the same time, the Strategy does not clearly define and characterise the mechanism that would perform the most important interrelationship function between general Russian civic consciousness (and the national unity based on it) and ethno-cultural diversity. The Strategy pays much attention to interethnic relations, and ethno-cultural diversity in most cases is treated only as a background. In particular, nothing is said about such important issues as the ethnic structure of the country, the existence of numerous ethnic groups, the situation and processes of their ethno-cultural development.

However, in the absence of analysis, or even the objective to monitor ethno-cultural diversity, it is difficult to expect its preservation and, especially, development. This cannot be achieved without preserving ethnic identity; however, this term does not appear in the text of the Strategy. In our opinion, latent ethnic identity is regarded as a negative phenomenon, and this is absolutely untenable when, together with ethnocultural diversity, it has become an important factor in modern development.

National and ethnic identities are significant types of social identity. National identity is a factor in the consolidation of a society on the basis of common interests and values. Expressing it prominently is the key to the political and intellectual unity of Russian society. Ethnic identity emerges as a manifestation of affiliation needs and, as such, is interrelated both with specific human needs, in particular with the need for regulatory measures, and with basic vital needs in the form of a need for self-preservation. Thus, in the conditions observed in the 1990s (a sharp decline in the degree of social relations organisation, the fragmentation of certain spheres of life and the degradation of political management systems), ethnic identity has become the most subjectively significant factor that guarantees humans a certain level of social security and self-preservation.

This point should be considered when implementing national policy. It seems that one of the reasons for the negative reaction to the law on the Russian nation was the concern that its adoption could stimulate a certain "bullying" of ethnic identity. In fact, national and ethnic identities are not mutually exclusive. This is clearly demonstrated by the results of our sociological studies carried out in Siberian regions among the representatives of different ethnic groups. The task was to study national and ethnic identities both in juxtaposition with each other, and in relation to other types of social identity. To illustrate this, we will cite the data on three regions, the Republic of Altai, the Novosibirsk region and the Khanty-Mansi Autonomous Okrug - Yugra (KhMAO), which differ in constitutional and legal status, socio-economic development level, ethnic structure, and migration processes (Table 1). The types of identity considered (national, ethnic, macro-regional, regional, local) turned out to be quite significant for the respondents, although there are certain regional differences. Other types of identity are clearly pronounced, although there is a general domination of state-civic identity. 
Such a balance is favorable both for the development of the individual and society as a whole. The aim of national policy is to contribute not to their competitiveness, but to complementarity, a kind of integration which can contribute to social cohesion and unity.

Selecting the object of national policy is a conceptually important and simultaneously problematic issue. In the text of the Strategy, interethnic relations are considered to be its object. The Strategy emphasises them in particular. Monitoring them is an important national policy task, taking into account the setting of state and municipal systems to monitor the condition of interethnic relations and to alert early to any conflict situations. State monitoring in the sphere of interethnic and interdenominational relations is also one of the tasks of the Federal Agency for Nationalities.

Thus, the object of national policy in many cases is limited to interethnic relations and conflict situations, whereas it is necessary for it to regulate ethnosocial processes (ethno-economic, ethno-demographic, ethno-cultural, ethno-political and ethno-legal ones). This, in our opinion, should be regarded as a complex object of national policy. Interethnic relations are only a part, a definite manifestation, a product of more profound ethno-social processes, which need targeted state regulation. Without this, it is hardly possible to have a holistic view of the processes taking place in society.

Our position is to consider ethno-social processes in terms of interethnic interactions. Accordingly, the development of individual ethnoses (peoples) and ethnic groups appears as an interdependent development within a local (regional or municipal) interethnic community, which should be interpreted as an elementary empirical object in the study of ethnosocial processes. Thus, not only individuals, ethnic groups, public organisations, etc., but also interethnic communities in general should be taken into account by ethno-national policy, and the interdependent development of separate ethnic groups should be considered as a condition of general regional and local well-being.

In this view, we stress the need for organising and performing different types of monitoring of various specific objectives (ongoing, long-term, tactical and strategic). The Federal Agency for Ethnic Affairs has developed and implemented a system for automated monitoring of the state of interethnic and interfaith relations, and early warning of conflict situations in RF national policy. Although the agency's targets are quite numerous, it is supposed to provide a wide range of possibilities: from monitoring state programmes in the sphere of inter-national relations and the quality of provision of relevant public services to automatic reporting on various issues of national policy implementation and inter-national relations [15]. In general, this monitoring is a means of rapid response to the current situation. Under the authority of the RF President a monitoring system for information threats on the Internet should be developed. In the context of the significantly increased role of various types of elec-

Table 1. The degree of importance of different types of identity for representatives of ethnic groups, 2014, \% (N=1,430)

Types of identity

National identity (it is important to identify oneself as Russian) Ethnic identity (it is important to identify oneself as representative of your people)

Macro-regional identity (it is important to identify oneself as Siberian)

Regional identity (it is important to identify oneself as resident of your republic/county/region)

Local identity (it is important to identify oneself as resident of your village)

\begin{tabular}{ccccccc} 
Novosibirsk Region & \multicolumn{2}{c}{ KhMAO-Yugra } & \multicolumn{2}{c|}{ Republic of Altai } \\
Russians & $\begin{array}{c}\text { Other } \\
\text { ethnic } \\
\text { groups }\end{array}$ & Russians & $\begin{array}{c}\text { Other } \\
\text { ethnic } \\
\text { groups }\end{array}$ & Russians & Altai \\
\hline 86 & 81 & 91 & 89 & 93 & 88 \\
81 & 74 & 72 & 74 & 70 & 95 \\
\hline 80 & 74 & 65 & 70 & 78 & 79 \\
\hline & - & 61 & 76 & 72 & 94 \\
\hline 71 & 74 & 72 & 80 & - & - \\
\hline
\end{tabular}


tronic communication, such measures are extremely relevant and fully justified.

At the same time, the tasks of national policy are not limited to solving current problems, in particular, to preventing conflict situations and various threats. They also presuppose a regulatory impact on longterm processes and trends. Therefore, socio-cultural monitoring of the dynamics of interethnic communities should be implemented as an important condition for diagnosing and forecasting the main trends of ethno-social development. This suggests, among other things, diagnosing the social well-being of members of different ethnic groups and ethno-cultural development in general [21].

Another important issue concerns the appropriateness of regional models of state national policies. This formulation of the issue is largely explained by the conclusions of our specific ethno-sociological studies performed in different Siberian regions. In particular, the following main general tendencies in ethno-social processes were visible, and they denote the particularities of the ethno-social situation in specific regional interethnic communities in Siberia: the territorial reduction of the Russian population due to depopulation and migration processes, with its stable share in the total Siberian population; the growth of the number and the ethnocultural potential of the national-territorial entities' titular ethnic groups (the Yakuts, the Buryats, the Tuvinians, the Nenets, etc.); actualisation of national self-determination and adjustment of ethnic identity, ethnic fragmentation of "official" ethnic groups (e.g. in the Republic of Altai) with the prospect of ethnic reintegration; intensification of migration processes and territorial concentration of the representatives of different ethnic groups, which constitutes a form of adaptation and stimulates ethnic mobilisation and ethno-political consolidation; the strengthening of the national statehood of the indigenous Siberian peoples, the accumulation of ethno-symbolic capital and the revival of traditional institutions of power and government, the strengthening of ethnocracy; localisation of ethno-social processes in the regions, leading to the consolidation of ethno-territorial communities and regional patriotism.
Our research showed, firstly, different degrees of stagnation in the ethno-social situation and interethnic relations in different regions of Siberia; secondly, the unfavorable dynamics of these relations in public and expert consciousness (experts diagnosed stabilisation of the situation only over the last two years); thirdly, migration processes as one of the main factors of interethnic tension; fourthly, a lower level of social well-being among the local population, especially Russians, compared to newcomers; fifthly, the predominantly hostile attitude of the host community towards migrants; sixthly, the majority of respondents recognised the need for measures to limit the influx of migrants in their regions [17].

Ethnic groups are integrated into the RF through regional communities with various pressing problems. Therefore, an important task that has not been reflected in the Strategy is, in our view, the development of regional models of national policy. Their developers should take into account the objective processes that occur in local interethnic communities. At the same time, it is important to be guided not only by the general objectives and tasks of ethnonational policy, but also to take into account its regional specificities [3].

A very significant influence on the nature of the ethno-social processes in a number of regions is currently exerted by external and internal migration. Under this influence, the ethno-cultural mosaic is changing, the regional (local) interethnic communities are being restructured and the ethnic problem is being revived and modified. As our studies have shown, the local population (especially the Russians) is more critical than migrants when assessing many issues: other people's attitude towards their ethnicity, the level of satisfaction with different aspects of life, the dynamics of interethnic relations and their degree of severity, attitudes towards migrants, etc. Subjectively, it is the Russians who are more likely to experience discomfort and anxiety about the ethnosocial situation and interethnic relations that are associated mainly with migration processes. Therefore, not only the problem of adaptation and integration of migrants in the host community is urgent, but also the problem of insecurity of the local population and, as a consequence, its critical attitude towards mi- 
grants. In this regard, it is important to develop programmes to adapt the local population to the changing ethno-social situation.

In conclusion, we note that modern experience of mankind's development has shown the impossibility of a development model that is equally suitable for all countries and ethnic communities. Therefore, the fundamental scientific traditions that have developed in Russia in the field of national issues should not be sacrificed to the idea of fitting them, at all costs, into the modern "Western standard", especially when the Western world itself demonstrates an inability to cope with many pressing challenges.

The desire to impose a "universal" model meets active resistance and gives rise to many negative consequences and paradoxes, often leading to results that are directly opposed to the expectations of those behind the respective policy. The multitude of ethnic cultures in society gives rise to many identities that must be taken into account in national policy. Attempts to "find a total (political) identity in culture are doomed to failure, and the policy of universal identification, oriented toward culture, leads to violence" [24: 182].

The insufficient level of social well-being of the main part of the population and an unsatisfied feeling regarding social justice are one of the internal deterrent factors for achieving unity in Russian society and a developed sense of state-civic identity. There is also a public desire for a different level of law and order than exists in reality. This is evidenced by the results of our specific studies, as well as the conclusions of other sociologists. In the current conditions, changes in the economic and social policies of the state are urgent in the interests of the majority of the population, as well as the generation of conditions in which people could be proud of belonging to specific ethnic communities, and of their own citizenship.

\section{REFERENCES}

1. Abdulatipov R. G. 2007. Etnonacionalnaya politika v Rossiyskoy Federacii (koncepcii, praktika, realizaciya, perspektivy) [Ethno-National Policy in the RF (Concepts, Practices, Implementation, Prospects)], Moscow: Klassiks Stil.

2. Abdulatipov raskritikoval ideyu zakona o rossiyskoy nacii [Abdulatipov Criticizes the Idea of the Law on the Russian Nation]. Accessed on 29 January 2017.

http://onkavkaz.com/articles/3281-abdulatipov-raskritikoval-ideyu-zakona-o-rossiiskoi-nacii.html

3. Abramova M. A. et al. 2016. Regionalnye modeli nacionalnoy politiki sovremennoy Rossii [Regional Models of the National Policy of Modern Russia], vol. 1. Novosibirsk: Manuskript.

4. Berite stolko suvereniteta, skolko smozhete proglotit [Take as Much Sovereignty as You Can Swallow]. Accessed on 30 January 2017.

http://www.obeschania.ru/documents/promises/berite-stolko-suvereniteta-skolko-smozhete-proglotit

5. Chto vskryl na Kavkaze zakon "O rossiyskoy nacii" [What Has the Law "On the Russian Nation"

Revealed in the Caucasus?]. 2017. Accessed on 26 January 2017.

http://www.yaplakal.com/forum3/topic1520580.html

6. Connor U. 2000. "Natsiya - eto natsiya, eto gosudarstvo, eto etnicheskaya gruppa, eto"

[A Nation is a Nation, a State, an Ethnic Group, a...]. In: Etnos i Politika: Khrestomatiya, pp. 60-62. Moscow: University of Russian Academy of Education Publishing House.

7. Erokhina E. A. 2016. "Konceptualnye osnovaniya i principy regionalnogo modelirovaniya etnonacionalnoy politiki v sovremennoy Rossii” [Conceptual Foundations and Principles of Regional Modeling of Ethno-National Policy in Modern Russia]. The Siberian Journal of Philosophy, vol. 14, no 4, pp. 174-188.

8. Federal Target Programme "Ukreplenie edinstva rossiyskoy nacii i etnokulturnoe razvitie narodov Rossii (2014-2020 gody)" [Strengthening the Unity of the Russian Nation and the Ethno-cultural Development of the Peoples of Russia (2014-2020)]. Accessed on 21 September 2013. http://government.ru/media/files/41d4862001ad2a4e5359.pdf 
9. Fedotova N. N. 2013. "Koncepcii identichnosti v usloviyah nelineynoy sociokulturnoy dinamiki" [Concepts of Identity in the Context of Non-Linear Sociocultural Dynamics]. Knowledge. Understanding. Skill, no 2, pp. 52-62.

10. Huntington S. P. 2008. WHO ARE WE? The Challenges to America's National Identity. Moscow: AST Moscow.

11. Istoriya ministerstv po delam nacionalnostey v SSSR i Rossii [The History of the Ministries for Nationality in the USSR and Russia]. Accessed on 30 January 2017. https://ria.ru/spravka/20150313/1052460180.html

12. Medinskiy schitaet nadumannym spor vokrug termina, kotorym sleduet nazyvat grazhdan RF [Medinsky Considers Controversial the Debate about the Term to Be Applied to Russian Citizens]. 2016. Accessed on 30 January 2017. http://tass.ru/kultura/3798002

13. Meeting of the Council on Interethnic Relations. October 31, 2016. Accessed on 30 January 2017. http://www.kremlin.ru/catalog/keywords/26/events/53173

14. Meeting of the Presidium of the Council on Interethnic Relations. 2016. Accessed on 30 January 2017. http://www.kremlin.ru/events/administration/53482

15. O monitoringe sostoyaniya mezhnacionalnykh (mezhetnicheskih) i mezhkonfessionalnyh otnosheniy [On Monitoring the State of Interethnic and Interconfessional Relations]. Accessed on 15 June 2016. http://fadn.gov.ru/system/attachments/attaches/000/026/137/original/present_gis_3.09.pdf?1441744802

16. Oommen T. K. 2000. "Etniya i nacionalnost: kak izbezhat putanicy" [Ethnicity and Nationality: How to Avoid Confusion]. In: Etnos i Politika: Khrestomatiya, pp. 24-27. Moscow: University of Russian Academy of Education Publishing House.

17. Popkov Yu. V. (ed.). 2015. Etnosocialnye processy i etnonacionalnaya politika v regionah Sibiri [Ethno-Social Processes and Ethno-National Policy in Siberia]. Novosibirsk: SB RAS Publishing House.

18. Popkov Yu. V. 2013. O regionalnyh modelyah nacionalnoy politiki [On Regional Models of National Policy]. Vestnik Rossiyskoy nacii, vol. 6, no 6(32), pp. 51-66.

19. Popkov Yu. V. 2015. Nacionalnaya politika v Rossii: celevye ustanovki i regionalnye modeli [National Policy in Russia: Target Directives and Regional Models]. Sociological Studies. Sotsiologicheskie Issledovaniia, no 4, pp. 39-44.

20. Popkov Yu. V., Kostyuk V. G. 2015. Problemnoe pole nacionalnoy politiki v sovremennoy Rossii [The Problematic Field of National Policy in Modern Russia]. The Siberian Journal of Philosophy, vol. 13, no 3, pp. 71-80.

21. Popkov Yu. V., Kostyuk V. G. 2016. "Konceptualnye i metodicheskie osnovy organizacii sociokulturnogo monitoringa municipalnogo mezhetnicheskogo soobschestva" [Conceptual and Methodological Foundations of the Organisation of Socio-Cultural Monitoring of the Municipal Interethnic Community]. The Siberian Journal of Philosophy, vol. 14, no 3, pp. 149-160.

22. Putin prizval razrabotat zakon o rossiyskoy nacii. Vsem li ponravitsya? [Putin Calls for the Development of a Law on the Russian Nation. Will Everyone Like It?]. 2016. Accessed on 30 January 2017. http://www.yaplakal.com/forum1/topic1481522.html

23. Smishchenko R. S. 2008. Principy etnonacionalnoy politiki Rossiyskoy Federacii na sovremennom etape [Principles of the Ethno-National Policy of the RF at the Present Stage]. Izvestiya of Altai State University, no 4-1, pp. 191-194.

24. Smorgunov L. V. 2012. "Politicheskaya identichnost i ponyatie politicheskogo" [Political Identity and the Political Notion]. Polis. Political Studies, no 6, pp. 178-185.

25. Storonniki vyhoda Kalifornii iz SShA poluchili razreshenie na sbor podpi-sey [Supporters of California's Leaving the USA Receive Permission to Collect Signatures]. 28 January 2017. Accessed on 30 January 2017. http://news.vkupon.ru/index.html?id=1895962

26. Strategiya gosudarstvennoy nacionalnoy politiki Rossiyskoy Federacii na period do 2025 goda [The 2025 State National Policy Strategy of the RF]. Accessed on 28 January 2013. http://base.consultant.ru/cons/cgi/online.cgi?req=doc;base=LAW;n=139350

27. Tishkov V. A. 1998. "Zabyt o natsii (Post-natsionalisticheskoe ponimanie natsionalizma)" [Forget about the Nation (Post-Nationalist Understanding of Nationalism)]. Voprosy filosofii, no 9, pp. 3-26. 
28. Tishkov V. A. 2000. Natsiya - eto metafora [Nation Is a Metaphor]. Druzhba narodov, no 7, pp. 170-182.

29. Tishkov V. A. 2017. "Chto est natsiya. V poiskah rossiyskoy identichnosti” [What Is a Nation? In Search of Russian Identity]. Nezavisimaya gazeta. Accessed on 30 January 2017. http://www.ng.ru/stsenarii/2017-01-24/9_6910_nacia.html

30. Tramp podpisal ukaz o vozvedenii steny s Meksikoy [Trump Signs the Decree on the Construction of a Wall with Mexico]. 25 January 2017. Accessed on 30 January 2017. http://www.vestifinance.ru/articles/80418

31. Zorin V. 2012. My chasto vydaem prichinu za sledstvie i naoborot [We Often Give the Cause as the Effect and Vice Versa]. Rossiyskaya Federaciya segodnya, no 22, pp. 19-21. 